\title{
The ICC AND THE SeCurity CounCIL: How Much Support Is There For Ending
}

\section{IMPUNITY?}

\author{
Stuart Ford ${ }^{*}$
}

\section{INTRODUCTION}

This past year (2014) was not a good one for the International Criminal Court (ICC). The event that received the most attention was the collapse of the case against Uhura Kenyatta, the President of Kenya. ${ }^{1}$ Mr. Kenyatta had been accused of being criminally responsible for murder, rape, and persecution committed during post-election violence in Kenya. ${ }^{2}$ In early December 2014, Fatou Bensouda, the ICC's Prosecutor, withdrew charges against Mr. Kenyatta, claiming that the Kenyan government's refusal to cooperate had made it too difficult to obtain evidence against him. ${ }^{3}$ This led Professor Kontorovich to argue that the ICC's goal of ending impunity for serious violations of international criminal law is a utopian dream that cannot be achieved given the current state of the world. ${ }^{4}$ The dismissal of the case against Kenyatta does, indeed, raise serious questions, but Professor Dutton addresses the ramifications of the Kenyatta case in more detail. ${ }^{5}$

At almost the same time as the withdrawal of charges against Mr. Kenyatta, something else happened that received much less press coverage but may ultimately be as important to the future

\footnotetext{
* Associate Professor of Law at the John Marshall Law School in Chicago, Illinois, USA. This Article was greatly improved by the comments of Professor Yvonne Dutton, who read an earlier version. Priyavathi Reddy provided research assistance.

${ }^{1}$ See Marlise Simmons \& Jeffrey Gettleman, International Court Ends Case Against Kenyan President in Election Unrest, NEW YORK TIMES, Dec. 5, 2014 at 1.

${ }^{2}$ See Prosecutor v. Kenyatta, ICC-01/09-02/11-382-Red, Decision on the Confirmation of Charges Pursuant to Article 61(7)(a) and (b) of the Rome Statute, Pre-Trial Chamber II, at para. 428 (Jan. 23, 2012). Id. at 5 (explaining Mr. Kenyatta was also accused of other crimes against humanity, including forcible transportation and inhumane acts) .

${ }^{3}$ Prosecutor v. Kenyatta, ICC-01/09-02/11-983, Notice of withdrawal of the charges against Uhuru Muigai Kenyatta, at para. 1 (Dec. 5, 2014).

${ }^{4}$ See Eugene Kontorovich, A Court's Collapse, National ReviEw Online, Sept. 15, 2014, at 7.

5 See Yvonne M. Dutton, Enforcing the Rome Statute: Evidence of (Non) Compliance from Kenya, 26 INDIANA INT'L \& COMP. L. REV. 11-12 (2015).
} 
of the court. On December 12, 2014, Ms. Bensouda appeared before the United Nations (UN) Security Council to update them on the progress of the ICC's investigations in Darfur. She told the Council that conditions had worsened in Darfur and that crimes within the court's jurisdiction were occurring, including the widespread commission of rape and other sexual crimes. She went on to note that those indicted by the court continue to evade arrest. ${ }^{6}$ Then, in a stunning admission of defeat, she told the Security Council that she was suspending the investigation into events in Darfur and shifting the court's resources to other situations:

It is becoming increasingly difficult for me to appear before you and purport to be updating you when all I am doing is repeating the same things I have said over and over again. ... Given this council's lack of foresight on what should happen in Darfur, I am left with no choice but to hibernate investigative activities in Darfur as I shift resources to other urgent cases. ${ }^{7}$

The government of Sudan promptly declared victory: "The Sudanese people have defeated the ICC and have refused to hand over any Sudanese to the colonialist courts."

The suspension of the ICC's investigations in Darfur raises important questions about the court and its relationship with the Security Council. Can the court succeed without the Security Council's assistance? Why is the Security Council paralyzed? Is this situation likely to change? How much support is there for ending impunity in the Security Council and beyond? What do states mean when they say they support the ICC? By examining what states, both members of the

\footnotetext{
${ }^{6}$ See Office of the Prosecutor, Twentieth Report of the Prosecutor of the International Criminal Court to the UN Security Council Pursuant to UNSC 1593 (2005), at para. 1 (Dec. 15, 2014), http://www.icccpi.int/en_menus/icc/press\%20and\%20media/press\%20releases/Pages/20-UNSC-Darfur-OTP.aspx (last visited Dec. 15, 2014). [http://perma.cc/DH6R-3DV5].

7 BBC News, ICC Prosecutor Shelves Darfur War Crimes Inquiries, BBC NEws, 1 (Dec. 12, 2014), http://www.bbc.com/news/world-africa-30458347 (last visited Dec. 15, 2014) [http://perma.cc/8YZN-D5PB].

${ }^{8}$ Shadi Bushra, Sudan's Bashir Claims Victory Over ICC After Court Shelves Darfur Probe, ReuTERS (Dec. 13, 2014), http://www.reuters.com/article/2014/12/13/us-sudan-icc-bashir-idUSKBN0JR0K520141213 (last visited Dec. 15, 2014) [http://perma.cc/XX6Q-H7UV].
} 
Security Council and the broader membership of the General Assembly, have said recently about the ICC and impunity, I hope to draw some conclusions about the likelihood of long-term success for the ICC.

\section{BACKGROUND}

While Sudan has had a history of conflict, violence and autocratic rule since it obtained independence, the conflict in Darfur began in late 2002 or early 2003 when rebel groups began an armed insurgency against Sudanese government forces. ${ }^{9}$ The government responded with a campaign of indiscriminate attacks on villages in Darfur that killed tens of thousands of civilians and resulted in widespread torture, rape, and the destruction of property. ${ }^{10}$ The attacks tended to follow a common pattern, with villages being attacked by a combination of Sudanese government soldiers driving vehicles and Janjaweed fighters riding horses and camels. ${ }^{11}$ In some instances, the attacks were supported by helicopters and planes operated by the Sudanese armed forces. ${ }^{12}$ The attackers would kill civilians, including women and children, burn houses, schools, and hospitals, and destroy wells. ${ }^{13}$ They would then steal any movable property, including livestock, before leaving. ${ }^{14}$ Several hundred thousand people died during the first several years of the conflict, ${ }^{15}$ and the widespread destruction of villages caused approximately two million Darfurians to flee the violence. ${ }^{16}$ The UN-appointed International Commission of Inquiry on Darfur investigated the

\footnotetext{
${ }^{9}$ Report of the Int'l Comm'n of Inquiry on Darfur to the United Nations Secretary-General at paras. 62-63, UN Doc. No. S/2005/60 (Jan. 25, 2005).

${ }^{10} I d$. at IIII $184-186,238-240$.

${ }^{11} I d$. at II 242.

${ }^{12} I d$. at II 243.

${ }^{13} I d$. at II 242.

${ }^{14} I d$.

${ }^{15}$ See BBC News, Darfur Deaths Could be 300,000', BBC News (Apr. 23, 2008), http://news.bbc.co.uk/2/hi/africa/7361979.stm (noting that while the government of Sudan estimated that there had been 10,000 deaths, the World Health Organization had estimated that more than 200,000 people had died in Darfur) [http://perma.cc/S2EM-FPUX].

${ }^{16}$ Report of the Int'l Comm'n of Inquiry on Darfur, supra note 9, at III 226, 229-230.
} 
situation on behalf of the international community and concluded that the government of Sudan was responsible for acts that "very likely" constituted war crimes and crimes against humanity. ${ }^{17}$

In March 2005, the Security Council responded with a resolution that found the violence in Sudan constituted a threat to international peace and security, and "refer[red] the situation in Darfur . . . to the Prosecutor of the International Criminal Court." ${ }^{18}$ It also "decide[d] that the Government of Sudan ... shall cooperate fully with and provide any necessary assistance to the Court and the Prosecutor. ..."19 The resolution passed with eleven affirmative votes and four abstentions. At the time, simply obtaining Security Council approval for a referral was considered a success ${ }^{20}$ given U.S. opposition to the court. ${ }^{21}$

Shortly after Resolution 1593, the Prosecutor opened a formal investigation into the ongoing violence in Darfur. ${ }^{22}$ In July 2008, the Prosecutor requested an arrest warrant be issued for Omar Al Bashir, the President of Sudan. ${ }^{23}$ Several months later, Pre-Trial Chamber I granted the request. ${ }^{24}$ Before doing so, it reviewed the information submitted by the Prosecution in support of the arrest warrant, and concluded that there were reasonable grounds to believe that President Bashir was criminally responsible for war crimes and crimes against humanity committed in Darfur. $^{25}$

\footnotetext{
${ }^{17} I d$. A t $t[630$.

${ }^{18}$ S.C. Res. 1593, UN Doc. No. S/RES/1593 (2005), at para. 1 (Mar. 31, 2005).

${ }^{19} \mathrm{Id}$. at $\mathrm{Ql} 2$.

${ }^{20}$ See M. Cherif Bassiouni, The ICC - Quo Vadis?, 4 J. InT'L CRIM. JUsT. 421, 425 (2006) (noting that the referral "engendered much initial euphoria").

${ }^{21}$ See, e.g., Corrina Heyder, The U.N. Security Council's Referral of the Crimes in Darfur to the International Criminal Court in Light of U.S. Opposition to the Court: Implications for the International Criminal Court's Functions and Status, 24 BERKELEY J. INT'L L. 650, 660-661 (2006) (describing U.S. opposition to the ICC).

${ }^{22}$ Press Release from Luis Moreno-Ocampo, Chief Prosecutor, ICC, The Prosecutor of the ICC opens investigation in Darfur, Doc. No. ICC-OTP-0606-104 (2005).

${ }^{23}$ Public Redacted Version of the Prosecutor's Application under Article 58, Doc. No. ICC-02/05-157-AnxA, 1, 112 (July 14, 2008).

${ }^{24}$ See Prosecutor v. Bashir, Doc. No. ICC-02/05-01/09-1, Warrant of Arrest (Mar. 4, 2009).

${ }^{25}$ Id.
} 
The ICC eventually issued arrest warrants against a number of senior Sudanese government officials for war crimes and crimes against humanity committed during the conflict in Darfur. In each case, the Pre-Trial Chamber reviewed the evidence submitted by the Prosecutor and concluded that there was reasonable grounds to believe that the accused person was criminally responsible for acts within the jurisdiction of the court. ${ }^{26}$ These included warrants for the arrest of Ahmad Muhammad Harun, the former Minister of the Interior, and Abdel Raheem Muhammad Hussein, the current Minister of Defense. ${ }^{27}$ And then, nothing happened.

\section{The CURRENT Situation}

Nearly ten years has passed since the Security Council's referral of Darfur to the ICC, yet there has been almost no tangible progress. The violence in Darfur has not stopped and government forces continue to engage in indiscriminate and disproportionate attacks against civilians. ${ }^{28}$ Rather than improving over time, the situation in Darfur actually worsened in $2014 .{ }^{29}$ Moreover, the most recent round of peace talks between the government of Sudan and various rebel groups collapsed in early December. ${ }^{30}$ And the UN peacekeeping force in Darfur is set to shrink or even disappear, despite the increasing violence ${ }^{31}$ because the peacekeepers have found it virtually impossible to be

\footnotetext{
${ }^{26}$ See Rome Statute, Art. 58(1) (July 1, 2002) (requiring the Pre-Trial Chamber to examine the information submitted by the Prosecutor and determine whether there are "reasonable grounds to believe that the person has committed a crime within the jurisdiction of the Court" before issuing an arrest warrant).

27 Int'l Crim. Ct., Situation in Darfur, INT'L CRIM. CT. (Mar. 1, 2012) http://www.icccpi.int/en_menus/icc/situations\%20and\%20cases/situations/situation\%20icc\%200205/Pages/situation\%20icc0205.aspx (last visited December 16, 2014) [http://perma.cc/MQ9D-WBUN].

${ }^{28}$ See U.N. SCOR, 69th Sess., 7337th Mtg. at 3, UN Doc. No. S/PV.7337 (Dec. 12, 2014) ("My Office's factual indicators seem to illustrate a similar pattern of indiscriminate and disproportionate attacks against civilians by the Rapid Support Forces.”).

${ }^{29}$ See Id. at 2 (noting in her presentation to the Security Council, the Prosecutor noted that "the situation in Darfur continue[s] to deteriorate.").

${ }^{30}$ Sudan: Peace Talks End Without Deal, New York Times, Dec. 10, 2014, at A8.

${ }^{31}$ See Somini Sengupta and Jeffrey Gettleman, U.N. Set to Cut Force in Darfur as Fighting Rises, New YoRk TIMES, Dec. 24, 2014, at A8.
} 
effective in the face of attacks by Sudanese forces and their proxies and the hostility of the Sudanese government. ${ }^{32}$

None of the indicted members of the government of Sudan have been handed over to the ICC. Indeed, the government of Sudan considers it a victory that it has been able to frustrate attempts to arrest the indictees. ${ }^{33}$ ICC officials have never been permitted to conduct investigations in Sudan. ${ }^{34}$ The government of Sudan refuses to communicate with the court and simply returns the court's correspondence unopened. ${ }^{35}$ And the indicted officials, including President Omar Al Bashir, continue to make state visits to other countries. ${ }^{36}$ At this stage, the Sudanese government can plausibly declare victory over the international community.

Thus, it was disheartening but unsurprising to hear the Prosecutor admit defeat. Now, it is true that it was not a complete defeat. The arrest warrants will continue to be in effect. And there is no statute of limitations for serious violations of international criminal law. ${ }^{37}$ Thus, so long as the accused are alive there is the possibility that they will be arrested and stand trial. Moreover, the Prosecutor's language — she said the investigations would be put "on hold" rather than ended ${ }^{38}$ - indicates that she could reopen her investigations later, if the circumstances change. Nevertheless, her decision to suspend the investigations was an admission that the success of the ICC's work in Darfur is almost entirely out of its hands. It depends on either a regime change in

\footnotetext{
${ }^{32} I d$.

${ }^{33}$ See Bushra, supra note 8.

${ }^{34}$ See Cécile Aptel Williamson, Justice empowered or justice hampered: The International Criminal Court in Darfur, 15 AFR. SECURITY REV. 20, 25-26 (2006) (noting that ICC investigators had not been allowed into Sudan). See also Victor Peskin, Caution and Confrontation in the International Criminal Court's Pursuit of Accountability in Uganda and Sudan, 31 HUM. RTS. Q. 655, 667 (2009).

35 Twentieth Report of the Prosecutor, supra note6, at 198.

${ }^{36}$ See Twentieth Report of the Prosecutor, supra note6, at $\mathbb{1} 10$ (explaining that during the second half of 2014, Bashir traveled to Qatar, Saudi Arabia, Egypt, and Ethiopia).

${ }^{37}$ See, e.g., Rome Statute, Art. 29 (July 1, 2002) ("The crimes within the jurisdiction of the Court shall not be subject to any statute of limitations.").

${ }^{38}$ See U.N. SCOR, 6th Sess., supra note 27, at 2.
} 
Sudan that brings to power a government willing to cooperate, or much more muscular action by the Security Council to compel the existing Sudanese regime to cooperate. As things stand, neither seems likely in the short term.

\section{The ICC Has the Legal Authority to Conduct Investigations AND Prosecutions Arising Out of the Violence in Darfur}

The legal issues that arise out of the relationship between the ICC and the Security Council are relatively straightforward: the ICC has the necessary legal authority to succeed. Unfortunately, as the ICC's experience with Darfur shows, legal authority is at best only weakly connected to success. First of all, the Rome Statute gives the Security Council the authority to refer matters to the ICC, and this serves as a proper jurisdictional basis for the court to investigate the situation, ${ }^{39}$ although using this authority may not always be a good idea. ${ }^{40}$ Next, the Security Council has authority under Chapter VII of the United Nations Charter to take measures not including the use of armed force to resolve threats to international peace and security. ${ }^{41}$ This includes the authority to subject Sudan to the jurisdiction of the court against its will and to order Sudan to cooperate with the court. ${ }^{42}$ Thus, there is little doubt that the referral was lawful, the ICC properly has

\footnotetext{
${ }^{39}$ See Luigi Condorelli \& Annalisa Ciampi, Comments on the Security Council Referral of the Situation in Darfur to the ICC, 3 J. INT'L CRIM. JUST. 590, 592 (2005) (addressing the Security Council's referral of the situation in Darfur to the ICC was consistent with Article 13(b) of the Rome Statute, which permits the Court to exercise jurisdiction when a situation is "referred to the Prosecutor by the Security Council acting under Chapter VII of the Charter of the United Nations.").

${ }^{40}$ See Louise Arbour, The Relationship Between the ICC and the UN Security Council, 20 Global GovernanCE: REV. MUlTILATERALISM \& INT'L ORGS. 195, 198 (2014) (arguing that the ICC's "legitimacy hinges to a large degree on voluntary acceptance of its complementarity jurisdiction" and that "Security Council referrals, by their nature a political and coercive measure, threaten to undermine the voluntary acceptance" of the court's jurisdiction).

${ }^{41}$ U.N. Charter, art. 41.

${ }^{42}$ Dapo Akande, The Legal Nature of Security Council Referrals to the ICC and its Impact on Al Bashir's Immunities, 7 J. INT'L CRIM. JUST. 333, 335 (2009) (noting that Sudan is not a member of the Rome Statute and would not, absent the Security Council resolution, have any obligation to cooperate with the ICC). See infra note 45 (noting that Article 86 of the Rome Statute imposes an obligation on member states to cooperate with the court).
} 
jurisdiction over the situation in Darfur, and Sudan is legally obligated to cooperate with the court. $^{43}$

The Security Council also possesses the authority to compel other states to cooperate with the ICC as part of its investigation in Darfur. ${ }^{44}$ However, Resolution 1593 did not compel such cooperation. Rather, it simply "urge[d]" other states to cooperate. ${ }^{45}$ This language, when used in Security Council Resolutions, is aspirational rather than mandatory. ${ }^{46}$ On the other hand, the Rome Statute imposes a general obligation upon members to cooperate with the court. ${ }^{47}$ The result is that Sudan is obligated to cooperate by virtue of Resolution 1593, while other members of the Rome Statute are obligated to cooperate by virtue of Article 86 of the Rome Statute. Non-member states, other than Sudan, are not obligated to do anything, although the Security Council did "urge" them to cooperate.

\section{So Why Has the ICC Made So Little Progress in Darfur?}

As a matter of law, the ICC has most of what it needs to conduct its investigations and obtain custody of the accused - most notably jurisdiction over the situation and a Security Council Resolution requiring Sudan to cooperate. In practice, however, the legal issues have proved to be relatively unimportant compared to the political issues. This was recognized early on by a number of commentators. For example, Cherif Bassiouni, writing in 2006, described the Darfur referral as a "near mission impossible" because of the expected lack of political support from the Security Council and the likelihood that Sudan would not cooperate with the court. ${ }^{48}$

\footnotetext{
${ }^{43}$ See Condorelli \& Ciampi, supra note 38, at 592-593.

${ }^{44} \mathrm{Id}$. at 593 (noting that the Security Council could have used the authority granted to it under Article 41 of the United Nations Charter to obligate all states to cooperate with the ICC); Heyder, supra note 20, at 655 ("Under Article 41, the Security Council could adopt a resolution compelling all member states to give full effect to the Security Council's decision to refer the Sudan case to the ICC.").

${ }^{45}$ S.C. Res. 1593, UN Doc. No. S/RES/1593 (2005), at II 2 (Mar. 31, 2005).

${ }^{46}$ See Condorelli \& Ciampi, supra note 38, at 593.

${ }^{47}$ See Rome Statute, Art. 86 (July 1, 2002).

${ }^{48}$ See M. Cherif Bassiouni, The ICC - Quo Vadis?, 4 J. INT’L CRIM. JUST. 421, 425-426 (2006).
} 
Ms. Bensouda laid the blame for the failure of the court's work in Darfur at the feet of Sudan and the Security Council. First, the Prosecutor blamed Sudan for its refusal to cooperate:

[T]he Government of Sudan . . . has the primary responsibility and is able to fully implement the Court's warrants of arrest consistent with its sovereign authority. Notwithstanding this clear responsibility, it has consistently failed to do so. At the same time, it has also failed to provide any meaningful measure of justice at the national level. ${ }^{49}$

Next, the Prosecutor blamed the Security Council. She said that not once in ten years had the Security Council taken any concrete action to help the ICC succeed in Darfur. ${ }^{50}$ And she told the Council that "unless there is a clear change of attitude and approach to Darfur in the near future," it was unlikely that the situation would change. ${ }^{51}$ She said that the continued deterioration of the situation in Darfur should "shock" the Council into action. ${ }^{52}$ Essentially she conceded that, without a dramatic change of heart by either the Council or Sudan, the ICC is unable to succeed in Darfur.

Of course, the Security Council has the authority to act to support the ICC. Sudan is in violation of its obligation to cooperate under Resolution $1593 .{ }^{53}$ Resolution 1593 was issued under Chapter VII of the United Nations Charter after a finding by the Council that the situation in Darfur is a threat to international peace and security. The continuing violence suggests that it is still a threat to international peace and security. This means the Council could take a variety of actions to respond to Sudan's intransigence. These actions could range from formally finding Sudan to be in violation of its legal obligations under Resolution 1593, through the imposition of sanctions, all

\footnotetext{
${ }^{49}$ See Record of the $7337^{\text {th }}$ Mtg., supra note 27 , at 3.

${ }^{50} I d$. at 2.

${ }^{51} \mathrm{Id}$.

${ }^{52} I d$.

${ }^{53}$ See Akande, supra note 41, at 335.
} 
the way up to the authorization of the use of force against Sudan. ${ }^{54}$ Just as clearly, the Security Council will do none of these things at the present time.

\section{A. The Threat of a Russian OR Chinese Veto}

The debate that followed the Prosecutor's dramatic announcement that she was suspending investigations in Darfur highlighted the divides among the Security Council's members. Ten states expressed support for the ICC, lamented the Security Council's paralysis, and criticized Sudan's refusal to cooperate. These were Australia, ${ }^{55}$ Jordan, ${ }^{56}$ the United Kingdom, ${ }^{57}$ Luxembourg, ${ }^{58}$ Argentina, ${ }^{59}$ the United States,${ }^{60}$ Lithuania,${ }^{61}$ South Korea, ${ }^{62}$ Chile,${ }^{63}$ and France.${ }^{64}$ Their language was clear and unequivocal. For example, the Australian representative said that the Council had "failed the victims of Darfur," ${ }^{65}$ while the representative of Luxembourg said that the ICC needed the "decisive support" of the Security Council ${ }^{66}$ and the French representative urged the Council to ensure that the ICC's arrest warrants were executed. ${ }^{67}$ The U.S. representative called the Council's inaction a "travesty" and urged the Council to "wake from [its] slumber." 68

The African states on the Security Council, on the other hand, were ambivalent about the ICC. The Nigerian representative, for example, condemned the violence in Darfur and called for

\footnotetext{
${ }^{54}$ See Christopher D. Totten \& Nicholas Tyler, Arguing for an Integrated Approach to Resolving the Crisis in Darfur: The Challenges of Complementarity, Enforcement, and Related Issues in the International Criminal Court, 98 J. CRIM. L. \& CRIMINOLOGY 1069, 1110-1112 (2008).

${ }^{55}$ See Record of the $7337^{\text {th }}$ Mtg., supra note 27, at 3-4.

${ }^{56} \mathrm{Id}$. at 6.

${ }^{57} \mathrm{Id}$. at 7.

${ }^{58} I d$. at 7-8.

${ }^{59} \mathrm{Id}$. at 9-11.

${ }^{60}$ See Record of the $7337^{\text {th }}$ Mtg., supra note 27, 11-13.

${ }^{61} I d$. at 13 .

${ }^{62} \mathrm{Id}$. at $13-14$.

${ }^{63} \mathrm{Id}$. at 14 .

${ }^{64} \mathrm{Id}$. at $15-16$.

${ }^{65}$ See Record of the $7337^{\text {th }}$ Mtg., supra note 27, at 4.

${ }^{66} \mathrm{Id}$. at 8 .

${ }^{67} I d$. at 16.

${ }^{68} \mathrm{Id}$. at 13.
} 
peace, but did not express support for the ICC or criticize the Sudanese government's lack of cooperation. ${ }^{69}$ Chad's representative did likewise, condemning the violence as a general matter, but hardly mentioning the ICC or Sudan's cooperation with the court. ${ }^{70}$ The Rwandan delegate complained that the Security Council had refused to defer the proceedings against Bashir as requested by a number of African states ${ }^{71}$ and that "continued reports of non-cooperation by African States" were counterproductive. ${ }^{72}$ Underlying this ambivalence is a concern among some African states that the ICC's focus on African problems shows that it has become a tool of great power politics. $^{73}$

Russia and China were even less supportive. The Russian delegate blamed the violence on "warring tribes" rather than the government of Sudan, praised the Sudanese government for its alleged attempts to maintain peace, and criticized the United States for imposing sanctions on Sudan. ${ }^{74}$ More generally, Russia opposes any action by the Security Council against Sudan. ${ }^{75}$ The Chinese delegate praised the Sudanese government for its efforts to "advance the political reconciliation process" and conspicuously did not call for Sudan to cooperate with the ICC. ${ }^{76}$ In fact, the Chinese delegate only mentioned the ICC once in his presentation — when noting that the Chinese position regarding "the handling of the Darfur issue by the International Criminal

\footnotetext{
${ }^{69}$ Id. at $4-5$.

${ }^{70} I d$. at 16.

71 The Rome Statute grants to the Security Council the right to defer ICC proceedings for a period of one year by passing a resolution under Chapter VII of the United Nations Charter. See Rome Statute, Art. 16. A number of African states have asked for a deferral of the ICC's proceedings in Darfur, but the Security Council has not done so. See Charles C. Jalloh, Dapo Akande, \& Max du Plessis, Assessing the African Union Concerns about Article 16 of the Rome Statute of the International Criminal Court, 4 AFR. J. LEGAL STUD. 5, 7-8 (2011).

${ }^{72}$ See Record of the $7337^{\text {th }}$ Mtg., supra note 27 , at 9.

${ }^{73}$ See Jalloh et al., supra note 71.

${ }^{74}$ See Record of the $7337^{\text {th }}$ Mtg., supra note 27 , at 5.

${ }^{75}$ See Somini Sengupta and Jeffrey Gettleman, U.N. Set to Cut Force in Darfur as Fighting Rises, NEW YORK TIMES, Dec. 25, 2014 (noting that Russia "staunchly backs the Bashir government" and the existence of "Russian resistance" to action by the Security Council) [http://perma.cc/D6A5-TXHD].

${ }^{76}$ See Record of the $7337^{\text {th }}$ Mtg., supra note 27 , at 8 .
} 
Court remains unchanged." "77 While he did not spell out that position explicitly, China's position is that it will veto any resolution that pressures Sudan to cooperate with the ICC. ${ }^{78}$

Despite the Security Council's paralysis, it is important to recognize that there is considerable support for the ICC and that the paralysis essentially comes down to the threat of a Russian or Chinese veto. Even if we assume the African states would vote against Security Council action rather than simply abstain, the number of states on the Security Council supporting the ICC outnumbers those who would vote against it ten to five. Thus, there are sufficient votes to pass a Security Council resolution providing support to the ICC, if there were no permanent member veto. ${ }^{79}$ However, those who oppose Security Council action include Russia and China, both of whom wield the veto. ${ }^{80}$ As a result, the Security Council is paralyzed and will not take any action to support the ICC or pressure Sudan to cooperate. Nor is this the only recent situation in which the threat of a veto has paralyzed the Council. The vote on referral of the situation in Syria to the ICC in May 2014 broke down along similar lines. Thirteen of the fifteen Security Council members supported referral, but the measure was vetoed by Russia and China. ${ }^{81}$

It would be wrong to conclude from the Security Council's paralysis in Darfur and Syria that the Security Council is opposed to action to end impunity. There is, in fact, broad support for

\footnotetext{
${ }^{77} I d$.

${ }^{78}$ See ICC Charges Against Uhuru Kenyatta Defended by Ocampo, BBC NEWS AFRICA (Dec. 16, 2014, 08:19 AM), http://www.bbc.com/news/world-africa-30498266 ("China is an ally of Sudan in the UN Security Council, and is bound to veto any action against [President Bashir], correspondents say."); Giorgio Cafiero, China's Sudan Challenge, FOREIGN POL'Y IN FOCUS (Feb. 7, 2013), http://fpif.org/chinas_sudan_challenge/ (“China's veto power has provided the Sudanese regime with impunity at the United Nations Security Council (UNSC). Beijing's threat to veto all resolutions targeting Sudan has empowered Bashir's regime to pursue its aggressive policies in Darfur without the threat of economic sanctions being imposed by the UNSC.") [http://perma.cc/2XEU-XN4A].

${ }^{79}$ See UN Charter, art. 27(3) (noting that Security Council decisions need affirmative votes by nine members but also require "the concurring votes of the permanent members").

${ }^{80}$ See UN Charter, art. 23(1) (noting that Russia and China are permanent members of the Security Council).

${ }^{81}$ See Record of the $7180^{\text {th }}$ Mtg., UN Doc. No. S/PV.7180, dated May 22, 2014, at 4 (noting that China and Russia voted against the draft resolution referring the situation in Syria to the ICC while the other thirteen members of the Security Council voted in favor of it).
} 
the ICC within the Council. Opposition to action, on the other hand, is narrow. Essentially, the opposition consists of Russia and China, and, absent the permanent member veto, the Security Council would already have acted in Sudan and Syria.

\section{B. BROAD SUPPORT FOR THE ICC IN THE GENERAL ASSEMBLY}

There is also considerable support for the ICC among the membership of the UN as a whole. On October 23, 2014, the Security Council held an open debate on the functioning of the Security Council and cooperation with the ICC. ${ }^{82}$ Thirty-four countries urged greater Security Council support for the ICC. ${ }^{83}$ Thirty-one countries spoke in support of limiting the permanent member veto in situations of mass atrocities. ${ }^{84}$ Moreover, a number of countries that spoke in support of the ICC, did so on behalf of coalitions of states. For example, Switzerland spoke on behalf of the Accountability, Coherence and Transparency Group (ACT). ACT is a group of twenty-three states that supports both the ICC and limiting the permanent member veto. ${ }^{85}$ Saint Lucia spoke on behalf of the "L.69 group," a group of 42 developing countries that supports "comprehensive reform" of the Security Council. ${ }^{86}$ Although the representative from Saint Lucia did not specifically mention the ICC, reforming the Security Council to limit or remove the

\footnotetext{
${ }^{82}$ See Record of the $7285^{\text {th }}$ Mtg., UN Doc. No. S/PV.7285, dated Oct. 23, 2014. So many states wished to speak that the meeting was adjourned and then resumed after lunch. See Record of the $7285^{\text {th }}$ Mtg., UN Doc. No. S/PV.7285 (Resumption 1), dated Oct. 23, 2014.

${ }^{83}$ The author read all of the speeches and coded them for support of ICC, support for Security Council reform (generally), and support for limiting the permanent member veto.

${ }^{84}$ There have been several recent proposals to have the permanent members of the Security Council commit not to use their vetoes in situations where mass atrocities are occurring. The most prominent recent proposal along these lines came from France. See, e.g., Laurent Fabius, A Call for Self-Restraint at the U.N., NEW YORK TIMES, Oct. 4, 2013. Such a voluntary code of conduct would avoid the problem that any proposal to amend the Charter to eliminate the veto would itself be subject to veto by any of the permanent members. See United Nations Charter, art. 108.

${ }^{85}$ See Record of the $7285^{\text {th }}$ Mtg., UN Doc. No. S/PV.7285, dated Oct. 23, 2014, at 26-27 (noting that the Swiss representative spoke in his "capacity as the Coordinator of the Accountability, Coherence and Transparency (ACT) group, a cross-regional group of 23 states" and expressing ACT's support for both the ICC and limiting the permanent member veto).

${ }^{86} \mathrm{Id}$. at 27-28.
} 
permanent member veto would effectively empower the Security Council to support the ICC. ${ }^{87}$ In other words, there is broad support among UN member states for changes that would remove the permanent member roadblock and permit the Council to support the ICC. ${ }^{88}$

In contrast, only four states were openly critical of the ICC or the Security Council's relationship with the ICC: Russia, Rwanda, Chad, and Egypt. ${ }^{89}$ The Russian delegate, for example, argued that the Security Council was already cooperating sufficiently with the ICC as evidenced by the fact that the Security Council permitted the Prosecutor to address it regularly. ${ }^{90} \mathrm{He}$ went on to suggest that the problem of Sudanese non-cooperation was the court's fault for trying to bring to justice senior public officials of states. ${ }^{91}$ The Rwandan delegate chastised the Council for failing to take any action on the request by African states for a deferral of the ICC's proceedings in Darfur, although he also said that Rwanda remained committed to "ensur[ing] accountability for the most serious crimes." 92 The representatives from Chad and Egypt echoed Rwanda's concerns about deferral of the ICC's investigations in Darfur. ${ }^{93}$ The Chinese delegate was ambiguous rather than overtly critical ("We believe that the ICC's efforts to seek justice should take into account the urgent needs of maintaining regional peace and stability"94) but in practice, China is opposed to action by the Security Council to support the ICC.

\footnotetext{
${ }^{87}$ See supra text accompanying notes 79-81 (noting that absent a permanent member veto, the Security Council would have already acted to support the ICC).

${ }^{88}$ See also infra notes 179-180 (noting that General Assembly Resolution 68/305, which expresses support for the ICC, had sixty-six sponsors and passed by consensus).

${ }^{89}$ See infra text accompanying notes 90-93.

${ }^{90}$ See Record of the $7285^{\text {th }}$ Mtg., UN Doc. No. S/PV.7285, dated Oct. 23, 2014, at 12.

${ }^{91} \mathrm{Id}$. at $12-13$.

${ }^{92} \mathrm{Id}$. at $14-15$.

${ }^{93} I d$. at 16 ; Record of the $7285^{\text {th }}$ Meeting of the Security Council, UN Doc. No. S/PV.7285 (Resumption 1), dated October 23, 2014, at 31 .

${ }^{94}$ See Record of the $7285^{\text {th }}$ Mtg., UN Doc. No. S/PV.7285, dated Oct. 23, 2014, at 11.
} 
The debate demonstrates that the positions of states within the General Assembly are quite similar to the positions of states within the Security Council. A clear majority of states spoke in favor of supporting the ICC and very few states spoke against it. ${ }^{95}$ Nor was the court's support limited to Western democracies. While most European states urged support for the ICC, so did many Central and South American states (including Costa Rica, ${ }^{96}$ Guatemala, ${ }^{97}$ Chile,${ }^{98}$ Mexico, ${ }^{99}$ Uruguay, ${ }^{100}$ Argentina, ${ }^{101}$ and Brazil ${ }^{102}$ ) as well as a number of Asian states (including South Korea $^{103}$ and Japan ${ }^{104}$ ).

The position of African states warrants particular study because, apart from Russia and China, opposition to the ICC appears to come largely from African states. Rwanda, Chad, and Egypt all criticized the Council's refusal to defer the proceedings in Darfur, ${ }^{105}$ but not all African states were negative about the court. Three African states were neutral (Morocco, Algeria, and Côte d'Ivoire), ${ }^{106}$ while two states, Nigeria and Botswana, called for greater support for the ICC. ${ }^{107}$ Moreover, even Rwanda and Egypt, two of the African states that were critical of the ICC,

\footnotetext{
${ }^{95}$ See supra text accompanying notes 83-94 (noting that thirty-four states urged greater support of the ICC, while only four states were critical of the ICC).

${ }^{96}$ See Record of the $7285^{\text {th }}$ Mtg., UN Doc. No. S/PV.7285, dated Oct. 23, 2014, at 28-29.

${ }^{97}$ Record of the $7285^{\text {th }}$ Meeting of the Security Council, UN Doc. No. S/PV.7285 (Resumption 1), dated October 23, 2014, at 4-5.

${ }^{98}$ See Record of the $7285^{\text {th }}$ Mtg., UN Doc. No. S/PV.7285, dated Oct. 23, 2014, at 8-9.

${ }^{99}$ Record of the $7285^{\text {th }}$ Meeting of the Security Council, UN Doc. No. S/PV.7285 (Resumption 1), dated October 23, 2014 , at 7-8.

${ }^{100} \mathrm{Id}$. at $14-15$.

${ }^{101}$ See Record of the $7285^{\text {th }}$ Mtg., UN Doc. No. S/PV.7285, dated Oct. 23, 2014, at 24-25.

${ }^{102}$ Record of the $7285^{\text {th }}$ Meeting of the Security Council, UN Doc. No. S/PV.7285 (Resumption 1), dated October 23, 2014, at 5-6.

${ }^{103}$ See Record of the $7285^{\text {th }}$ Mtg., UN Doc. No. S/PV.7285, dated Oct. 23, 2014, at 6-7.

${ }^{104} \mathrm{Id}$. at 30-31.

105 See Record of the 7285 ${ }^{\text {th }}$ Mtg., UN Doc. No. S/PV.7285, dated Oct. 23, 2014, at 14-15 (Rwanda); id. at 16 (Chad); Record of the $7285^{\text {th }}$ Meeting of the Security Council, UN Doc. No. S/PV.7285 (Resumption 1), dated October 23, 2014, at 31 (Egypt).

${ }^{106}$ Record of the $7285^{\text {th }}$ Meeting of the Security Council, UN Doc. No. S/PV.7285 (Resumption 1), dated October 23, 2014, at 25-26 (Morocco); id. at 34-35 (Algeria); id. at 31-32 (Côte d'Ivoire).

107 See Record of the 7285 ${ }^{\text {th }}$ Mtg., UN Doc. No. S/PV.7285, dated Oct. 23, 2014, at 13 (Nigeria); Record of the 7285 ${ }^{\text {th }}$ Meeting of the Security Council, UN Doc. No. S/PV.7285 (Resumption 1), dated October 23, 2014, at33-34 (Botswana).
} 
nevertheless called for a limit on the permanent member veto in situations involving mass atrocities. ${ }^{108}$ And Rwanda, the most critical state, reaffirmed that it was committed to ending impunity for mass atrocities. ${ }^{109}$

In effect, it appears that African views about the ICC's involvement in Darfur are mixed, with some states opposed, some neutral and some states in favor of supporting the ICC. The positions of African states match up fairly closely with whether they are members of the Rome Statute. Of the states that have criticized the ICC, Chad is a member of the Rome Statute, while Rwanda and Egypt are not. ${ }^{110}$ Of the states that were neutral, Côte d'Ivoire is a member state, while Morocco and Algeria are not. ${ }^{111}$ Both states that were supportive of the ICC (Nigeria and Botswana) are members of the Rome Statute. ${ }^{112}$ Given that there are thirty-four African states that are members of the Rome Statute, ${ }^{113}$ this suggests that the majority of African states are probably still (quietly) supportive of the ICC, even if a vocal minority is critical of it. Moreover, even those African states that are critical of the ICC's involvement in Darfur claim to be broadly supportive of ending impunity and lifting the stranglehold imposed by the permanent member veto. ${ }^{114}$

Further, there is some reason to believe that African states view the situation in Darfur as something of a special case. For example, all three of the African members of the Security Council at the time (Chad, Rwanda, and Nigeria) voted in favor of draft Security Council referral of the

\footnotetext{
${ }^{108}$ Record of the $7285^{\text {th }}$ Mtg., UN Doc. No. S/PV.7285, dated Oct. 23, 2014, at 14-15 (Rwanda); Record of the $7285^{\text {th }}$ Meeting of the Security Council, UN Doc. No. S/PV.7285 (Resumption 1), dated October 23, 2014, at 31 (Egypt).

${ }^{109}$ Record of the $7285^{\text {th }}$ Mtg., UN Doc. No. S/PV.7285, dated Oct. 23, 2014, at 15 (noting that Rwanda shared the ICC's goal to "fight impunity and ensure accountability for the most serious crimes").

110 See International Criminal Court, State Parties to the Rome Statute, available at http://www.icccpi.int/en_menus/asp/states\%20parties/Pages/the\%20states\%20parties\%20to\%20the\%20rome\%20statute.aspx (last visited Dec. 28, 2014) [http://perma.cc/8ATM-SF7C].

${ }^{111} I d$.

$112 \mathrm{Id}$.

${ }^{113} \mathrm{Id}$.

${ }^{114}$ See supra text accompanying notes 108-109.
} 
situation in Syria to the ICC. ${ }^{115}$ It is notable that Rwanda, the fiercest African critic of the ICC's handling of the situation in Darfur, was nonetheless willing to support the referral of the situation in Syria. ${ }^{116}$ This suggests that African opposition may be specific to Darfur rather than a generalized opposition to the ICC.

The positions of states during the attempt to refer the situation in Syria to the ICC show a similar pattern. The draft resolution that China and Russia vetoed ${ }^{117}$ had sixty-five sponsors. ${ }^{118}$ That support came from all over the world including many states in Europe, Central and South America, Africa, and the Middle East. Once again, Africa deserves special attention. Seven of the measure's sixty-five sponsors were African states: Botswana, the Central African Republic, Côte d'Ivoire, the Democratic Republic of the Congo, Libya, Senegal, and the Seychelles. ${ }^{119}$ Six of these seven countries (all but Libya) are also state parties to the Rome Statute. ${ }^{120}$ So, while Rwanda and a few other African states have been outspoken in their criticism of the court's investigation in Darfur, it appears the majority of African states, particularly those that are ICC members, are still generally supportive of the ICC.

In short, there is ample evidence that support for the ICC is broad, while opposition to the court is narrow. This level of support for the court is not surprising given that there are 122 state parties to the Rome Statute. ${ }^{121}$ To put that in perspective, there are only 193 members in the entire

\footnotetext{
115 See supra note 79.

116 See Record of the $7180^{\text {th }}$ Mtg., UN Doc. No. S/PV.7180, dated May 22, 2014, at 4 (noting that Rwanda voted in favor of the referral),

${ }^{117} \mathrm{Id}$.

118 See Draft Resolution, UN Doc. No. S/2014/348, dated May 22, 2014.

${ }^{119} \mathrm{Id}$.

120 See International Criminal Court, State Parties to the Rome Statute, available at http://www.icccpi.int/en_menus/asp/states\%20parties/Pages/the\%20states\%20parties\%20to\%20the\%20rome\%20statute.aspx (last visited Dec. 28, 2014) [http://perma.cc/8ATM-SF7C].

${ }^{121} I d$.
} 
United Nations. ${ }^{122}$ This means that more than $60 \%$ of all states are ICC members and thus presumably supporters of the ICC. Unfortunately, the states that oppose the ICC include China and Russia, both of which can use their veto power to block Security Council action. The result has been paralysis by the Council.

\section{The Permanent Members of The Security Council}

The key players in the relationship between the ICC and the Security Council are the permanent members. As shown above, but for the threat of a permanent member veto, it is likely that the Security Council would have already acted to support the ICC. Thus, understanding their motivations may make it easier to predict the future of relations between the Council and the court. For this purpose, I will use the framework developed by Professor Bosco in his book Rough Justice. ${ }^{123} \mathrm{He}$ argues that states will adopt one of three strategies for dealing with the ICC marginalization, control, or acceptance. ${ }^{124}$ States may try to marginalize the court by attacking the court's legitimacy or trying to prevent other states from supporting it. ${ }^{125}$ Another strategy is for states to try and control the court to ensure that it undertakes activities the state wants while avoiding those it does not want. ${ }^{126}$ This could be accomplished by conditioning state support on whether the court's actions are consistent with the state's interests. Finally, states can accept the court, which would entail consistently supporting the court even when its actions do not serve the state's political interests. ${ }^{127}$

122 See United Nations, Growth in United Nations Membership, 1945-present, available at http://www.un.org/en/members/growth.shtml\#text (last visited Jan. 26, 2016).

${ }^{123}$ See generally David Bosco, Rough Justice: The InTERnational Criminal Court in a World of Power PoLITICS (Oxford University Press 2014).

${ }^{124} I d$. at 11-17.

${ }^{125} \mathrm{Id}$.

${ }^{126} I d$.

${ }^{127} I d$. 
Britain and France are both firm supporters of the ICC and are often seen as the court's strongest allies on the Council. ${ }^{128}$ They are parties to the Rome Statute and speak regularly in support of the ICC. ${ }^{129}$ The United Kingdom describes itself as "a strong supporter of international justice in general and of the International Criminal Court in particular."130 Unlike Russia and China, who talk about balancing peace and justice, the United Kingdom takes the position that there cannot be lasting peace without justice ${ }^{131}$ and has urged all states to become members of the ICC. ${ }^{132}$ France similarly seems to favor justice in the peace vs. justice debate ${ }^{133}$ and has taken the unusual step of promoting a "code of conduct" between the permanent members under which they would agree not to veto resolutions in situations where mass atrocities are being committed. ${ }^{134}$ France and the United Kingdom also appear to be willing to go farther than most countries in taking concrete action to support the ICC. ${ }^{135}$ In Professor Bosco's framework, France and the United Kingdom have accepted the ICC. ${ }^{136}$

The United States was initially quite hostile to the ICC, ${ }^{137}$ even though it abstained from Resolution 1593 rather than vetoing it. ${ }^{138}$ For example, President Bush "officially nullified the Clinton administration's signature of the Rome Statute” and discontinued participation in ICC

\footnotetext{
${ }^{128}$ See David Kaye, The Council and the Court: Improving Security Council Support of the International Criminal Court (2013) at 9.

${ }^{129} \mathrm{Id}$.

${ }^{130}$ See Record of the $6849^{\text {th }}$ Mtg., supra note 141 , at 24.

131 Id. ("We have learned from history that there cannot be lasting peace without justice, accountability and reconciliation.").

${ }^{132} I d$. ("We need all States that have not yet done so to become parties to the Rome Statute . . .").

${ }^{133} I d$. at 23 ("Silence has never served peace or justice. The inability of the Council to demonstrate its unity against mass crimes is, rather, an incitement to the Syrian authorities to pursue the path of violence.").

${ }^{134}$ See Record of the $6849^{\text {th }}$ Mtg., supra note 141 , at 23.

135 See infra notes 183-187 (noting that the United Kingdom and France have indicated their willingness to arrest ICC indictees, among other things).

136 See David Bosco, Rough Justice: The International Criminal Court in a World of Power Politics (Oxford University Press 2014) at 15-17.

137 See Id. at 71-75.

${ }^{138}$ See supra notes 21-22.
} 
meetings. ${ }^{139}$ His ambassador to the United Nations, John Bolton, characterized the ICC as a threat to fundamental American values. ${ }^{140}$ Despite this initial hysteria, it was always likely that the United States would moderate its opposition to the ICC given that they share many similar goals. For example, the U.S. representative to the Security Council has said that "[s]trengthening the global system of accountability for the worst atrocities remains an important priority for the United States" and described preventing mass atrocities as both a "core national security interest" of the United States and a "moral responsibility." ${ }^{141}$ These are also core goals of the ICC. ${ }^{142}$ Indeed, President Obama has been considerably more supportive of the ICC than President Bush. For example, the United States has argued in favor of Security Council action to support the ICC's investigations in Darfur, ${ }^{143}$ and the United States voted for the referral of the situation in Syria to the ICC. ${ }^{144}$

Moreover, the United States has also worked behind the scenes to support the ICC. The United States is an active participant in meetings of the Assembly of States, it transferred ICC indictee Bosco Ntaganda to the court after he surrendered himself to the U.S. Embassy in Kigali, and the United States has deployed military advisers to help search for members of the Lord's Resistance Army who have been indicted by the ICC. ${ }^{145}$ Professor Kaye has described the United States as having a "close working relationship" with the court, ${ }^{146}$ although the recent self-referral

\footnotetext{
${ }^{139}$ See Heyder, supra note 21, at 661.

${ }^{140} \mathrm{Id}$.

${ }^{141}$ See Record of the $6849^{\text {th }}$ Mtg., UN Doc. No. S/PV.6849, dated Oct. 17, 2012 at 8.

${ }^{142}$ See Rome Statute, Preamble (noting that the ICC was established to ensure that "the most serious crimes of concern to the international community as a whole [do] not go unpunished" and to "put an end to impunity for the perpetrators of these crimes and thus contribute to the prevention of such crimes").

${ }^{143}$ See supra notes 60, 68.

${ }^{144}$ See supra note 81.

${ }^{145}$ See Kaye, supra note 128, at 10.

${ }^{146} I d$. at 9.
} 
by Palestine ${ }^{147}$ may cause tension in that relationship. ${ }^{148}$ Ultimately, the goals of the United States and the ICC are broadly aligned, but the United States has reservations about the existence of a truly independent international court that could constrain its conduct or indict its nationals. Given that the potential for ICC constraints on U.S. action would be greatest if the United States became a party to the Rome Statute, ${ }^{149}$ it seems unlikely that the United States will join the ICC in the foreseeable future.

The United States does not fit neatly into Professor Bosco's framework. While it had a program of active marginalization under President Bush, it now broadly supports the objectives of the court, which makes it seem like it accepts the court in some key ways. At the same time, it is committed to using its position on the Security Council to prevent the court from obtaining jurisdiction over U.S. nationals, ${ }^{150}$ which looks like a control strategy. The United States thus seems to shift between acceptance and control strategies depending on the issue. As a result, the United States does appear to be qualitatively different from Russia and China, which appear to simply be interested in controlling the court.

Russia has often blocked support for the ICC. At the same time, Russia claims to support the goals of the ICC: "It is clear that persons guilty of particularly serious crimes under international law must be brought before the Court."151 What should one make of what Russia says

\footnotetext{
147 See "The Prosecutor of the International Criminal Court, Fatou Bensouda, opens a preliminary examination of the situation in Palestine," ICC Press Release dated Jan. 16, 2015, Doc. No. ICC-OTP-20150116-PR1083 (noting that the Prosecutor had opened a preliminary examination into the situation in Palestine following Palestine's accession to the Rome Statute and its request for an investigation).

148 See Kaye, supra note 128 , at 10.

${ }^{149}$ This would have the effect of granting the ICC jurisdiction over acts committed by US nationals. See Rome Statute, Art. 12(2)(b).

150 This can be seen, for example, in the language that was inserted into Security Council Resolution 1593 that "decide[d] that nationals, current or former officials or personnel from a contributing State outside Sudan which is not a party to the Rome Statute . . . shall be subject to the exclusive jurisdiction of that contributing State . . ." See Security Council Resolution 1593, UN Doc. No. S/RES/1593 (2005), dated March 31, 2005, at 97.

${ }^{151}$ See Record of the $6849^{\text {th }}$ Mtg., supra note 141 , at 20.
} 
versus what it does? Russia attempts to justify its position by focusing on the relationship between the court and the Council. So, for example, the Russian representative has noted the difficulty of achieving "a proper balance between the interests of peace and punishing the guilty." 152 He has also stressed the need for the Council and the court to "interact within the framework of their respective mandates and with mutual respect." ${ }^{153}$ There are legitimate debates about how to balance peace and justice, but it seems more likely that Russia's position is about power, specifically the question of whether the ICC will be subordinate to the Security Council. Implicit in the Russian position is a belief that the ICC should either be formally subordinated to the Security Council ${ }^{154}$ or that, at the very least, the ICC should defer to the Security Council's leadership. ${ }^{155}$ Not coincidentally, this would give Russia an effective veto over ICC action by virtue of its veto over Security Council action. All this suggests that Russia's opposition to the ICC is pragmatic rather than principled. It also suggests that Russia will sometimes support the ICC and sometimes oppose it depending on whether it thinks ICC action advances Russian interests. ${ }^{156}$ Russia is using a strategy of control rather than marginalization.

Of all the permanent members, China appears to be the only one with a principled opposition to the ICC, although power concerns are also present. Historically, China has given great weight to the principles of non-intervention and sovereignty. ${ }^{157}$ This has carried through to

\footnotetext{
152 Id. at 19 .

${ }^{153} \mathrm{Id}$.

${ }^{154}$ See, e.g., Id. at 20 (suggesting that the ICC should not be able to exercise jurisdiction over the crime of aggression "in the absence of a definition of aggression by the Security Council" and that "in the absence of a direct instruction, Security Council resolutions do not abrogate the norms of general international law on the immunity of heads of State in office").

${ }^{155}$ See, e.g., Id. at 19 (characterizing the ICC as a "new tool" that the Council can use in maintaining international peace and security).

${ }^{156}$ See Kaye, supra note 128, at 13 (noting that Russia is likely to take a "case-by-case approach" to the ICC that will not depend particularly on principles of accountability and justice).

157 See, e.g., Chen Tiqiang, The People's Republic of China and International Law, 8 DALHOUSIE L.J. 3, 23-25 (1984) (describing Chinese support for the Five Principles of Peaceful Coexistence, including “mutual respect for each other's territorial integrity and sovereignty" and "mutual non-interference in each other's internal affairs").
} 
the present, with the Chinese representative to the Security Council stressing that the Council must be guided in its work by the "fundamental principles of respect for national sovereignty and noninterference in the internal affairs of States." 158 Thus, while China views the ICC as an "integral part of the international system," it believes that the ICC must also abide by the principles of nonintervention and sovereignty. ${ }^{159}$ This suggests that China will generally be supportive of or at least ambivalent about the ICC's work when a state has consented to the Court's jurisdiction, but will generally oppose the use of the Security Council to subject a state to the court's jurisdiction against its will..$^{160}$

On the other hand, Professor Kaye suggests that concerns about non-interference and sovereignty may be less relevant today than they have been in the past for China. ${ }^{161}$ Particularly as China becomes more powerful militarily and politically, it may be less committed to a policy of non-interference because of the constraints such a policy imposes on its freedom of action. As with Russia and the U.S., there also appears to be a concern that a strong independent Court could be a potential threat. ${ }^{162}$ Like Russia, China thinks the best solution to the potential difficulties created by an independent ICC is to have the ICC defer to the Security Council. ${ }^{163}$ This would, of course, give China an effective veto over ICC action. Ultimately, China will be predisposed to oppose Security Council action that subjects a state to ICC jurisdiction against its will, although it

\footnotetext{
158 See Record of the $6849^{\text {th }}$ Mtg., supra note 141 , at 12 .

${ }^{159} \mathrm{Id}$.

${ }^{160} \mathrm{Id}$. ("States bear the primary responsibility to punish international crimes, eliminate impunity and achieve justice. The ICC can supplement but not replace national jurisdictions"). See also Record of the $7285^{\text {th }}$ Mtg., supra note 82 , at 11 ("The ICC should strictly abide by the principle of complementarity ....").

161 See Kaye, supra note 128, at 11.

${ }^{162} I d$. at 10 ("Officials of both countries are said to harbor concerns about a possible ICC focus on their own domestic conflicts. ...").

${ }^{163}$ See Record of the $6849^{\text {th }}$ Mtg., supra note 141 , at 12 ("Since the Charter entrusts the Security Council with the primary responsibility for the maintenance of international peace and security, we hope that the ICC will exercise caution in carrying out its functions and avoid impeding the work of the Security Council . .."). See also Record of the $7285^{\text {th }}$ Meeting of the Security Council, supra note 82, at 12 ("The ICC should ... support the Council's efforts to fulfil its responsibilities under the Charter.").
} 
will also factor in pragmatic considerations of how ICC action would affect its interests. ${ }^{164}$ Like Russia, China seeks to control the court rather than accept it. ${ }^{165}$

The ICC can count on France and Britain to support it. ${ }^{166}$ They have both accepted the ICC's goals and methods. The ICC can also probably count on U.S. support on most issues, unless it initiates a prosecution of a U.S. national, at which point the U.S. might shift back to a strategy of active marginalization. ${ }^{167}$ By the same token, the ICC can probably count on Russia and China to use their position as permanent members of the Security Council to try to control the court. ${ }^{168}$ This will mean that Russia and China will use their vetoes to protect themselves and their allies. To the extent that the court is willing to defer to Russia and China's interests in its selection of situations to investigate, it could probably neutralize that opposition, but sacrificing its independence would be anathema to the court, which is founded on the ideal of an "independent permanent International Criminal Court . . . with jurisdiction over the most serious crimes of concern to the international community as a whole."169

\section{What Does It Mean For STATES To SUPPORT THE ICC?}

Throughout this Article, I have talked about whether states support the ICC. States are described as supporting the ICC if their representatives call for supporting the court before the Security Council. But what does it mean to support the ICC? Take, for example, the statement of Chile during the Security Council debate that followed the Prosecutor's announcement that she was suspending investigations in Darfur. Chile's representative reiterated his country's "support

\footnotetext{
${ }^{164}$ See, e.g. ICC Charges Against Uhuru Kenyatta Defended by Ocampo supra note 78, at 4 (suggesting that China has blocked action on Darfur, in part, because Sudan is an ally).

165 See Bosco, supra note 136, at 14-15.

${ }^{166}$ See supra text accompanying notes 128-136.

${ }^{167}$ See supra text accompanying notes 137-150.

${ }^{168}$ See supra text accompanying notes 151-165.

${ }^{169}$ See Rome Statute, Preamble.
} 
for the Court and for the work of its Prosecutor." ${ }^{170} \mathrm{He}$ urged the Prosecutor to continue investigating potential crimes in Darfur, stressed the need for the Council to work with the Court to ensure its success, and urged all states to cooperate with the Court. ${ }^{171} \mathrm{He}$ did not, however, make any concrete proposals for how to accomplish these goals. Nor is Chile alone. A number of states made similar statements of general support that lacked any proposals for specific action. ${ }^{172}$

It is impossible to tell from Chile's statement if it would support any particular initiatives to put pressure on Sudan to cooperate with the court. It is possible that Chile would support concrete action, but it is equally possible that its support for the ICC extends only to praising it publicly. If the latter is true, then Chile's support is empty. Unless states are willing to take some concrete action that pressures Sudan to cooperate, it is unlikely that support for the court will translate into success for the court. After all, even Russia and China have said they support the ideas of justice and accountability in the abstract, ${ }^{173}$ even if in practice, they prevent the Security Council from acting to effectuate those principles. ${ }^{174}$

Luckily, there have been a number of calls for the Security Council to take specific actions. Looking at these can give us some sense of what states mean when they say they "support" the ICC, as well as an idea of what actions the Council would likely take if the threat of a permanent member veto was removed. The proposal that appears to have the most support is for the Security Council to create a monitoring mechanism, most likely in the form of a permanent subsidiary body, which would review state compliance with the Council's ICC-related resolutions and recommend

\footnotetext{
${ }^{170}$ See Record of the $7337^{\text {th }}$ Mtg., supra note 28 , at 14.

${ }^{171} \mathrm{Id}$.

172 See, e.g., Record of the $7337^{\text {th }}$ Mtg., supra note 28, at 13-14 (Republic of Korea).

173 See, e.g., supra text accompanying note 151.

${ }^{174}$ See, e.g., supra text accompanying note 81 (noting that Russia and China vetoed referral of the situation in Syria to the ICC).
} 
action the Council should take to achieve compliance. The creation of a formal monitoring mechanism has been endorsed by a significant number of states. ${ }^{175}$

Another proposal that has significant support is for the United Nations to pay for the costs of Security Council referrals. Both the Security Council resolution that referred the situation in Darfur to the ICC and the draft resolution that would have referred the situation in Syria stated that "none of the expenses incurred in connection with the referral ... shall be borne by the United Nations." 176 This was somewhat unexpected because the drafters of the Rome Statute had assumed that the United Nations would pay for the expenses incurred by referrals. ${ }^{177}$ Several states have spoken against the Council's refusal to pay for referrals. ${ }^{178}$ In addition, a General Assembly resolution was passed by consensus in 2014 that noted the need to fund the ICC's "expenses related to investigations and prosecutions" incurred as a result of "situations referred to the Court by the Security Council." 179 The resolution was sponsored by sixty-six states and adopted by consensus in the General Assembly. ${ }^{180}$

There also appears to be moderate support for a number of slightly stronger proposals. For example, a number of states support a proposal that the Security Council should, as a matter of course, impose targeted sanctions on individuals who have been indicted by the ICC. ${ }^{181}$ In addition,

\footnotetext{
${ }^{175}$ See Record of the $7337^{\text {th }}$ Mtg., supra note 28, at 4 (Australia); id. at 10 (Argentina); Record of the $7285^{\text {th }}$ Meeting, supra note 82, at 13 (Nigeria); id. at 19 (Jordan); id. at 20 (Luxembourg); id. at 21 (United States of America); id. at 23 (France); id. at 26 (Switzerland); id. at 30 (Liechtenstein); Record of the $7285^{\text {th }}$ Meeting of the Security Council (Resumption 1), supra note 82, at 3 (Romania); id. at 7 (Sweden); id. at 8 (Mexico); id. at 9 (The Netherlands); id. at 10 (Italy); id. at 11 (Germany); id. at 12 (Pakistan); id. at 16 (Czech Republic); id. at 18 (Portugal); id. at 35 (Poland); $i d$. at 37 (Hungary).

176 See S.C. Res. 1593, supra note 116, at II 7. See also Draft Res., UN Doc. No. S/2014/348, at If 8 (May 22, 2014).

177 See Rome Statute, Art. 115(b).

${ }^{178}$ See Record of the $7337^{\text {th }}$ Mtg., supra note 28, at 11 (Argentina); Record of the $7285^{\text {th }}$ Mtg., Resumption 1), supra note 82, at 5 (Brazil); id. at 9 (The Netherlands); id. at 16 (Czech Republic).

${ }^{179}$ See G.A. Res. 68/305 at 2 (Sept. 16, 2014).

${ }^{180}$ See U.N. GAOR, 68 ${ }^{\text {th }}$ Sess., $107^{\text {th }}$ plen. Mtg. at 20-22, , UN Doc. A/68/PV.107, (Sept. 9, 2014).

${ }^{181}$ See Record of the $6849^{\text {th }}$ Mtg., supra note 141, at 23 (France); Record of the $7337^{\text {th }}$ Mtg., supra note 28 , at 4 (Australia); Record of the $7285^{\text {th }}$ Mtg., supra note 82, at 25 (Argentina); Record of the $7285^{\text {th }}$ Mtg. (Resumption 1), supra note 82, at 3 (Romania).
} 
a number of countries have stated quite baldly that Sudan is in violation of its obligation to cooperate with the Court in Resolution $1593 .^{182}$ The logical consequence of this would be passage of a second resolution declaring that Sudan has breached its legal obligations under Resolution 1593.

Several stronger proposals have also been made, but there appears to be weaker support for these proposals. So, for example, France has proposed that the Council and the United Nations adhere to a rule that would generally prohibit contact with anyone who has been indicted by the ICC. ${ }^{183}$ A handful of other states also support this. ${ }^{184}$ The United Kingdom has proposed that all future referrals by the Security Council should include a legally binding obligation on all states to cooperate with the Court. ${ }^{185}$ The Netherlands supports this position. ${ }^{186}$ A small number of states have also indicated that they would implement the arrest warrants if given the opportunity. ${ }^{187}$ Finally, Hungary has proposed the creation of "clear and public criteria" that the Security Council would agree to follow in deciding both when to refer matters to the ICC and how to ensure accountability for such referrals. ${ }^{188}$

The first thing to note is that a significant number of states have said on the record that they would be willing to take concrete action to support the ICC. For most states, support does mean more than just praising the ICC during public debates. Moreover, it is quite likely that some of the states that took no position on particular proposals for action would nonetheless vote in favor of them if given the opportunity. On the other hand, it is also noticeable that the stronger the proposal,

\footnotetext{
${ }^{182}$ See Record of the $7337^{\text {th }}$ Mtg., supra note 28, at 12 (United States); id. at 13 (Lithuania); Id. at 15 (France); Record of the $7285^{\text {th }}$ Meeting (Resumption 1), supra note 82, at 10 (Italy); id. at 15 (Uruguay).

${ }^{183}$ See Record of the $6849^{\text {th }}$ Mtg., supra note 141 , at 23.

${ }^{184}$ See Record of the $7337^{\text {th }}$ Mtg., supra note 28, at 4 (Australia); id. at 10-11 (Argentina).

185 See Record of the $6849^{\text {th }}$ Mtg., supra note 141 , at 24.

186 See Record of the $7285^{\text {th }}$ Mtg., (Resumption 1), supra note 82, at 9 (The Netherlands).

${ }^{187}$ See Record of the $7337^{\text {th }}$ Mtg., supra note 28, at 7 (United Kingdom); id. at 10 (Argentina); Id. at 16 (France).

${ }^{188}$ Record of the $7285^{\text {th }}$ Mtg., (Resumption 1), supra note 82 , at 38.
} 
the smaller the number of states willing to publicly endorse it. This suggests, unsurprisingly, that states vary in the strength of the action they would take to support the ICC, with a large number of states willing to take moderate action and a smaller number willing to take stronger action.

So, if the threat of a Russian or Chinese veto were lifted, what action could we expect the Security Council to take? And what effect would it have, if any, on the success of the Court? There is broad support for the creation of a formal body within the Security Council tasked with monitoring compliance with ICC-related resolutions. It is unclear, however, how useful that would be. At best, the monitoring body would be able to make recommendations to the Security Council. It is unlikely that it would be empowered to take action on its own authority. Thus, it would not lead automatically to concrete action. On the other hand, having formal recommendations for action might make it more likely that the Council acted on those recommendations.

There also appears to be broad support for having the United Nations pay the costs of Security Council referrals. This might well have permitted the Prosecutor to continue her investigations in Darfur by providing the court with a dedicated funding source for those investigations. ${ }^{189}$ But, of course, simply continuing the investigations does not seem to materially increase the likelihood of success because Sudan would probably continue to block those investigations.

There appears to be moderate support for implementing targeted sanctions against ICC indictees and for a formal finding that Sudan is in violation of Resolution 1593. These steps would put greater pressure on Sudan, although they would also be less likely to occur. There is a debate about the utility of sanctions regimes, but in theory they apply pressure to the sanctioned

\footnotetext{
${ }^{189}$ See Record of the $7337^{\text {th }}$ Mtg., supra note 28, at 2 (suggesting that the decision to suspend the investigation in Darfur was driven in part by “an environment where [the OTP's] limited resources for investigations are already overstretched").
} 
individuals to comply with their obligations. ${ }^{190}$ A formal finding that Sudan was in violation of Resolution 1593 would similarly put pressure on Sudan by highlighting its intransigence and increasing its isolation in the international community. Of course, neither is likely to force Sudan into cooperating overnight.

Only a few states publicly support the strongest proposals, but these are also the proposals most likely to help the court succeed. Imposing a legal obligation on all states to cooperate with the ICC through a Security Council resolution passed under Chapter VII of the United Nations Charter would make it much harder for states to justify not arresting President Bashir if he could be found in their territory. This would, in turn, make it much harder for him to travel and further increase Sudan's isolation. Similarly, a public commitment by states to arrest ICC indictees would also serve to isolate President Bashir and apply pressure to his regime.

What is conspicuously missing is any proposal to use the Security Council's powers under Chapter VII of the Charter to authorize states to use force to arrest those indicted by the ICC. While this would have the strongest potential impact on the court's success, no state is willing to support such a proposal. Moreover, even if it were adopted by the Security Council, it seems relatively clear that no state would be willing to risk a confrontation with Sudan to enforce such a resolution.

Would any of these actions, assuming they were undertaken, improve the likelihood of the Court's success in Darfur? Counterfactual questions are impossible to answer with certainty. The most likely steps (a formal monitoring mechanism and payment of referral costs by the UN) seem to have the least chance of affecting Sudan's decision-making. The next most likely steps (placing ICC indictees on a sanctions list and formally finding that Sudan was in violation of Resolution

\footnotetext{
190 See generally, e.g., Jon Hovi et. al., When Do (Imposed) Economic Sanctions Work?, 57 WoRLD POLITICS 470 (2005); Daniel W. Drezner, Sanctions Sometimes Smart: Targeted Sanctions in Theory and Practice, 13 INTERNATIONAL STUDIES REVIEW 96 (2011).
} 
1593) would certainly apply pressure to the Sudanese regime and isolate it internationally, but the Sudanese regime has already survived years of international isolation. It is far from certain that these acts would change matters. The least likely steps (for example, imposing a legal obligation on all UN member states to arrest President Bashir) would arguably have the most impact, but even complete isolation from the international community might not be sufficient to pressure the Sudanese government to cooperate. On the other hand, sustained international pressure did cause Serbia to reverse course and cooperate with the International Criminal Tribunal for the former Yugoslavia, ${ }^{191}$ so we cannot say with certainty that these actions would have no effect. Ultimately, the actions of a more democratic Security Council would probably increase the likelihood of the court's success in Darfur, although probably not by a large amount.

\section{CONCLUSION}

There are several conclusions one can draw from all of this. First, the ICC is weak when compared to states. Even states that are themselves relatively weak and isolated, like Sudan, have been able to frustrate the ICC. ${ }^{192}$ If the government simply refuses the ICC access to the country, it becomes extremely difficult to conduct investigations. ${ }^{193}$ Moreover, prosecutions of senior leaders inevitably need insider witnesses who can tie those leaders to the crimes that are occurring. Governments are in an excellent position to apply pressure to such insiders to prevent them from testifying. ${ }^{194}$ And, as the experience in Sudan has shown, the government can make it virtually impossible for the court to obtain custody over the accused. After many years of trying, the

\footnotetext{
191 See supra notes 199-200.

192 See supra Section III (describing how Sudan has been able to frustrate the ICC's efforts to investigate the situation in Darfur). See also Dutton, supra note 5 (describing how Kenya was able to present the appearance of complying with its obligations to the ICC while simultaneously undermining and obstructing the ICC's investigations).

${ }^{193}$ See Record of the $7337^{\text {th }}$ Mtg., supra note 28, at 7 (noting the inability of ICC officials to travel to Darfur).

194 See Williamson, supra note 34, at 26.
} 
Prosecutor has essentially admitted that the Darfur cases have reached a dead end as a result of Sudanese obstruction. ${ }^{195}$

Second, when the ICC is investigating senior public officials in a state that actively opposes the ICC's work, as it has been in the situations in Darfur, Libya, and Kenya, the ICC cannot succeed without the support of the international community. In these situations, the power imbalance between the ICC and the state means that the ICC will have a difficult time. The targets of the investigation will have a strong incentive to obstruct the investigation and can use the resources of the state to accomplish that goal. ${ }^{196}$ To be successful, the ICC requires support from other states who can apply pressure to the recalcitrant state to persuade it to cooperate. ${ }^{197}$ In theory, one of the best venues for coordinating support for the ICC is the Security Council because it has the authority to impose sanctions and other measures on a state that refuses to cooperate. In practice, this has not worked because both Russia and China oppose strong Security Council action.

Third, as much as the situation looks intractable now, there are ways that it could change. A change in the Sudanese regime that brought to power a new government that was not so invested in blocking the ICC action would change the situation radically. ${ }^{198}$ As an example of this, Serbia opposed the International Criminal Tribunal for the former Yugoslavia (ICTY) when Slobodan Milošević was President. When a new government came to power, Serbia's position changed and

\footnotetext{
195 See supra text accompanying note 7.

196 See supra notes 192-194.

197 See Victor Peskin, Caution and Confrontation in the International Criminal Court's Pursuit of Accountability in Uganda and Sudan, 31 HuMAN RIGHTS QUARTERLY 655, 659-660 (2009).

${ }^{198}$ Id. at 677 (noting that President Bashir would "be most vulnerable to being arrested and handed over to [the ICC] if and when he falls from power in Khartoum”).
} 
Milošević was sent to The Hague to be tried. ${ }^{199}$ Of course, this was partly a result of strong external pressure by the United States and others to comply with the ICTY's arrest warrants or face the loss of international aid ${ }^{200}$ which tends to support point two above about the necessity of international support for international tribunals to be successful.

The other way the situation could change is by breaking the deadlock in the Security Council. At the moment this looks unlikely. Russia and China are more interested in controlling the ICC than empowering it, and one can reasonably expect them to continue to wield their vetoes to protect their interests and their allies. However, that may not be the case forever. For a time in the 1990's, it seemed like Russia might align itself with the West. That seems less likely now, but could change in the future as the current Russian system is probably unstable. ${ }^{201}$ China is already deeply embedded in the current international order and is becoming ever more closely tied to it, ${ }^{202}$ and it may eventually transition to an electoral democracy. ${ }^{203}$ In the event that Russia and China become liberal democracies, their strategies with regard to the court would probably shift from control to acceptance. At that point, the likelihood of a permanent member veto would go down dramatically.

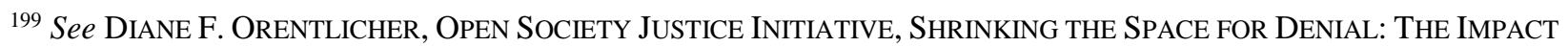
OF THE ICTY IN SERBIA, 28 (2008) (noting that Milošević was sent to the ICTY after he lost an election and the incoming government authorized his transfer).

${ }^{200} I d$. at 28-29. See also Bosco, supra note 136, at 67-68.

${ }^{201}$ See generally Lilia Shevtsova, The Next Russian Revolution, 111 CURRENT HISTORY 94 (Oct. 2012) (arguing that the current Russian government is unstable although it is unclear whether that will mean a shift towards liberalism, a long slow decline under increasingly autocratic and repressive regimes, or a violent collapse).

202 See G. John Ikenberry, The Illusion of Geopolitics: The Enduring Power of the Liberal Order, ForeIGN AFFAIRS, May/June 2014, at 9-10.

${ }^{203}$ See Dinping Guo, The Growth of Intra-Party Democracy and Its Implications for China's Democratic Future, 7 FudAN Journal OF THE HUMANITIES AND Social SCIENCES 1 (2014) (suggesting that current reforms within the Chinese Communist Party could pave the way for broader democratic reforms). But see Eric X. Li, The Life of the Party: The Post-Democratic Future Begins in China, 92 ForeIGN AfFAIRS 34 (2013) (arguing that the Chinese Communist Party can sustain its grip on power and that there is no large constituency in China calling for democracy).
} 
The fourth conclusion one can draw from the ICC's experience in Darfur is that there is broad support for ending impunity among the states of the world. As unlikely as an end to Security Council paralysis seems right now, it is important to keep that paralysis in perspective. Opposition to the ICC is narrow. It essentially boils down to two states that wield the veto. Support for the ICC, on the other hand, is broad and deep. It is strong in Europe, North America, Central America, and South America. There is still considerable support for the ICC in Africa, although there are also critics. Finally, there is some support for the ICC in Asia, with both South Korea and Japan supporting it. ${ }^{204}$ Many Asian states, however, appear to be on the sidelines - neither actively supporting nor opposing the ICC. ${ }^{205}$ There is no continent that is overwhelmingly opposed to the court. Should events occur that remove the threat of a Russian or Chinese veto, the Security Council could move rapidly to support the ICC.

Fifth, it appears that many states would be willing to take concrete action to support the ICC. If the threat of a Russian or Chinese veto was removed, the steps that would be both most likely to occur and most useful would be for the UN to pay for the cost of referrals, for ICC indictees to be put on the UN's targeted sanctions lists, and for the Security Council to formally find that Sudan is in breach of its obligations under Resolution 1593. While none of these would guarantee success, collectively they would support the ICC while pressuring Sudan to cooperate. A small number of states would favor even bolder action.

\footnotetext{
${ }^{204}$ See supra text accompanying notes 103-104 (noting that Japan and South Korea support the ICC).

${ }^{205}$ For example, Thailand's representative never even mentioned the ICC when it spoke to the Security Council. See Record of the $7285^{\text {th }}$ Meeting of the Security Council, UN Doc. No. S/PV.7285 (Resumption 1), dated October 23, 2014, at 2-3. The Indonesian representative similarly ignored the ICC. Id. at 18-19. The Malaysian representative at least mentioned the ICC, but his comment was so vague as to be virtually meaningless. Id. at 22 (noting that "the intersection of the roles of the Security Council and the International Criminal Court (ICC) also raises certain questions about the need to further clarify the relationship between the two bodies").
} 
I agree with much of what Professor Kontorovich has said about the ICC's weakness compared to states. ${ }^{206}$ It is true that the ICC, standing alone, has little chance of succeeding when governments are willing to use the machinery of the state to oppose it. But despite the recent failures in Kenya and Darfur, there is still reason to believe that the ICC can succeed. Of course, it cannot succeed on its own and will need support from the international community, but this is not as unlikely as Professor Kontorovich believes. He claims that the collapse of the Kenyatta case in Kenya "shows that supposed international norms have not been 'internalized' by the 'international community." "207 I disagree. While there is opposition to the ICC, that opposition is quite narrow and his claim that the international community has not internalized the norms of international criminal justice does not seem to be true. Rather, an examination of recent debates about the ICC shows that the majority of states do want an end to impunity and that many states would be willing to take concrete action to further that goal. This bodes well for the eventual success of the court.

States whose senior officials are under threat by the ICC are likely to be extremely motivated to obstruct the ICC, while those states that support international criminal justice are likely to be relatively diffuse in that support. ${ }^{208}$ There will also be spoilers like China and Russia who see political or economic advantage in providing shelter to states like Sudan. ${ }^{209}$ Thus, paralysis may well be the norm for the short to medium term. On the other hand, the majority of states do care about international criminal justice and ending impunity. Of course, it will rarely be the only thing they care about and states will weigh their concern for justice against their other

\footnotetext{
${ }^{206}$ See Kontorovich, supra note 4.

207 Id. at 5.

${ }^{208}$ See generally Kenneth A. Rodman, Darfur and the Limits of Legal Deterrence, 30 HUMAN RIGHTS QUARTERLY 529 (2008).

${ }^{209}$ See Ikenberry, supra note 202, at 9 (arguing that Russia and China are "spoilers at best" who are increasingly hemmed in by the rise of liberal democracies in Asia and Eastern Europe).
} 
motivations when deciding how assertive to be in support of the ICC. But the fact that there is broad support for ending impunity among the majority of nations suggests that the trend over time will be towards greater enforcement. Or, to paraphrase Dr. Martin Luther King Jr., the evidence suggests that the arc of history will bend towards justice. ${ }^{210}$

${ }^{210}$ Dr. King was himself paraphrasing the nineteenth century abolitionist Theodore Parker. See Jamie Stiehm, Oval Office rug gets history wrong, THE WASHINGTON POST, Sept. 4, 2010. 